\title{
ON THE EARLY IRRIGATION OF GYPSEOUS LANDS IN SPAIN
}

\author{
Juan Herrero ${ }^{1 *}$ \\ ${ }^{1}$ Estación Experimental de Aula Dei, CSIC, Av. Montañana 1005, 50059 Zaragoza, Spain \\ *jhi@eead.csic.es \\ ABSTRACT
}

Gypseous lands occur mainly in arid regions of the world, where irrigation is required for profitable agriculture. The study of gypseous soils has been neglected for years in the main stream of the soil science. Agriculture and more recently the environmental concerns are challenging research in the countries that have extensive gypsum outcrops. Those challenges became obvious at least from the 1960's, when the development of some of these countries led to the construction of new irrigation schemes and associated infrastructures. This paper presents examples of documents about agriculture on gypseous soils in Spain which might be illustrative for similar situations in other regions of the world.

KEY WORDS: agriculture; aridity; gypsic; gypsum; irrigation; soils.

\section{INTRODUCTION}

The study of crop systems on gypseous soils has been neglected for years, in part because of the scorn of these soils given their constraints for supporting life (Fig. 1). Botanists and ecologists distinctly recognized gypsophilous plants in countries that have gypsiferous soils, e.g.: Huguet $(1925,1929)$, Johnston (1941), Braun-Blanquet and Bolòs (1957), Le Houérou (1960), or Parsons (1976), while until recent years, studies on agronomy, soils, or related subjects have been scarce or absent. The world extent and distribution of gypseous soils is not fully known, but estimates range from one to two millions $\mathrm{km}^{2}$ (Casby-Horton et al., 2015), being noteworthy that these soils are most common in arid and undeveloped countries where the soils are now under pressure for agriculture and also pose concerns about the environment and biodiversity.

Others have reviewed some of the reasons why gypseous soils have been neglected in research, e.g., Herrero and Poch (1998), Herrero et al. (2009), Casby-Horton et al. (2015). The references in these articles show that neglect affected the methods of description and classification, and the study of the genesis, constitution and properties. The lability of gypsum $\left(\mathrm{CaSO}_{4} \cdot 2 \mathrm{H}_{2} \mathrm{O}\right)$ necessitates simple precautions in the preparation of the samples of gypseous 
soils for lab analyses but it provides easy and reliable methods for the gypsum content determination, as reviewed by Herrero et al. (2016). In addition, determining the particle-size distribution has been a challenge (Pearson et al., 2015). Specific concepts and terms for soil profile (Fig. 2) descriptions in the field (Schoeneberger et al., 2012) and under the microscope (Poch et al., 2010) have been developed recently. Most of the approaches used in the reviewed studies are penetrating the soil science despite some misunderstandings (Herrero and Mandado, 2016), which occur commonly when new methods or perspectives appear in any field of knowledge.

The references cited above provide general information about the research on gypsiferous soils. In the mid-20 $0^{\text {th }}$ Century, soil scientists in Spain studied lab methods for quantifying gypsum content in soils (Albareda et al., 1954, 1962) perhaps motivated by the inconveniences that occurred during and after the transformation of rainfed gypseous lands to irrigation (Fig. 3). In their book, which was published in three editions since 1945, Tamés \& Peral (1965) note the frequent presence of gypsum in Spanish soils, and the importance of its presence for the correct interpretation of the chemical analyses of soils. The book discriminates the methods for determining sodium, potassium and magnesium based on whether the soil is gypsiferous. Ruiz (1977) studied the routine rapid determination of sulfate and moisture content of gypsiferous materials for public works. In Spain, further advances in methods for the analysis of gypsum in soils occurred at the beginning of 21st century (Artieda et al., 2006; Lebron et al., 2009).

Huguet (1929) and Kubiëna (1952) emphasized the scientific importance of gypseous soils in Spain and adopted specific terms for them. In the 1960s, several contracts with the 55 European Research Office of the US Department of Army produced reports in which the gypsiferous soils were recognized and described, e.g.: Albareda et al. (1960, 1961, 1964, 1966). The memories accompanying the maps produced by Guerra et al. (1968); Guerra \& Monturiol (1970) also described gypseous soils, and Hernando et al. (1963) conducted experiments on soil fertility. Other documents might be in the gray literature. Later, the concepts and nomenclature of several versions of the Soil Taxonomy System (Soil Survey Staff, 1999) were used in Spain [see the review by Herrero \& Porta (1991) fordocuments from 1973 to 1988]. 
Spain is the only European country in which gyprock outcrops are common. The Ebro Valley, NE Spain, has a significant extent of surficial gypsiferous materials, resulting in an average annual supply to the sea of $35 \mathrm{Tm}$ of gypsum per $\mathrm{km}^{2}$ of surface area, or $2.9510^{6} \mathrm{Tm}$ per year (Navas, 1991). Mariño (1986) provides additional information about the export of soluble salts by the Ebro River.

Gypsiferous materials caused damages to irrigation canals that were built from the $19^{\text {th }}$ Century to the 1960s (Llamas, 1958), which required practical solutions for their repair (Faci, 1959). The economic assessments of the new irrigation schemes (Gómez-Ayau, 1961) recognized the difficulties in building irrigation canals in gypseous terrains and in identifying crops that are suited for gypsiferous soils. In 1962, the frequent failures related with gypsum in canals, tunnels, roads, and other infrastructures led to a dedicated meeting, the "I Coloquio Internacional sobre las Obras Públicas en los Terrenos Yesíferos" (First International Colloquium on Public Works in Gypsiferous Terrains), in which the problems in the many public works undertaken in previous years were discussed. The Colloquium provided the occasion for publishing the first comprehensive account of the gypsiferous geological materials in Peninsular Spain and Balearic Islands (Macau and Riba, 1962), which contains two very useful maps. The document was a key source for information on the extent and distribution of gypsiferous terrains in Spain, until the review by Escavy et al. (2012).

From 1945 to 1970, Spain faced soil problems in the implementation of several new irrigation schemes; however very few scientific publications on these subjects were produced. One example treating soil salinity but also gypsum is Ayers et al. (1960) while for gypseous soils the most widely cited is the booklet by van Alphen and De los Ríos (19711960), while for gypseous soils, the most widely cited is the booklet by Van Alphen \& De los Ríos (1971), which was a substantial information source for different kinds of documents, for example, Stoops \& Ilaiwi (1981), and FAO $(1986,1990)$.

The world scarcity of agricultural research about gypseous soils, coupled with linguistic and cultural barriers, and the general difficulties for communication constituted a drawback for the irrigation schemes built in the $20^{\text {th }}$ century. Many problems had to be solved by engineers in charge of new irrigation districts based on the empirical knowledge of farmers. This was the case of the central Ebro Valley, where the aridic soil moisture regime (Soil Survey Staff, 1999) necessitates irrigation for profitable agriculture, a need exacerbated by the low water retention capacity of gypseous soils (Moret and Herrero, 2015). 
Roman inscriptions about irrigation found at the banks of Ebro River (Fatás \& Beltrán, 1997; Beltrán, 2006) allow surmising that tracts of gypseous lands were already irrigated at the Roman times, 2100 years ago. Continuous agriculture for more than 200 years is documented on gypseous soils irrigated by the Canal Imperial de Aragón whose construction ended in 1790. It is noteworthy that its final projected section, with about $30 \mathrm{~km}$ long, was not completed because of the collapse and dissolution of the gypseous materials (Bolea-Foradada, 1986, p. 300).

Included here as Supplementary material is a transcription of an unpublished 1967 Report (in Spanish) by F. De los Ríos whose role as the agronomical engineer responsible for 40 years of the irrigation projects starting in the 1940's in the Ebro Valley reinforces the significance of this document. The report contains information about yields, water management, ground collapses, land prices, and other details of farmers' experience with irrigating gypseous soils by basin and border inundation, the irrigation technology available at the moment based on the precise leveling of each plot. The report summarizes the direct experience of the farmers, some of whom were using water diverted from the Ebro River via the Canal Imperial and others were using the then ten-year-old irrigated districts in which water came from the Pyrenees.

De los Ríos (1984a) published some of the data contained in his Report. His favorable valuation of the yields in irrigated gypseous lands appeared in newspapers (De los Ríos, 1984b). The observations of De los Ríos conform to the current local experience about irrigated crops in the Ebro Valley and are consistent with the results of Laya et al. (1998) who used an objective method to study the relationship between gypsum content in the soil and irrigated alfalfa yield.

\section{CONCLUSIONS}

The information and references provided here should be useful in other regions of the world and inspire research about the agriculture on gypseous lands, especially those under irrigation. The advent of pressurized irrigation and the use of plastics have lessened many of the problems associated with flood irrigation, and research on hydric and other properties of gypseous soils are needed. The new era in irrigation marked by increasing competition for water and the use of pressurized systems ought to consider the practical knowledge gained by engineers and technicians in charge of the irrigation districts installed in the last century. Several pertinent references are provided in this article, and the Section "Supplementary material" revives one rare document about the irrigation of gypseous lands. The rampant loss 
of the farmers experience caused by the rural exodus and the industrialization of agriculture underscores the relevance of gathering information from all sources, which often involves exhuming documents from the gray literature and making them accessible on the internet.

\section{ACKNOWLEDGEMENTS}

This work has been funded by the Spanish Government under the project CGL2015-71360-P and by the Spanish National Research Council (CSIC) under the project Icoop-2016SU0015.

\section{REFERENCES}

Albareda JM, Hernando V, Bilbao G. 1954. Determinación de yeso en suelos. Anales de Edafología y Fisiología Vegetal 13: 451-462 .http://hdl.handle.net/10261/122937. Albareda JM, Hernando V, Bilbao G. 1962. Suelos yesosos I. Determinación del yeso. Acta Salmanticensia 5: 224-251. http://hdl.handle.net/10261/122933.

Albareda JM, Guerra A, Fernández-Galiano E, Monturiol F, García-Vicente J. 1964. Study of the physical properties of soils through interpretation of aerial photographs, I. Final Technical Report. Contract No. DA-91-591-EUC-2652. http://hdl.handle.net/10261/136379.

Albareda JM, Monturiol F, Badorrey T, Guerra A, Monserrat P. 1966. Photoanalysis of the main relief forms in geological materials and soils of Spain and their relationship to trafficability conditions. Final Technical Report. Contract No. DA-91-591-EUC-3713. http://hdl.handle.net/10261/135152.

Albareda JM, Guerra A, Monturiol F, Pérez-Mateos J, García-Vicente J, Alonso JJ. 1961. Study of the soils of the Ebro Valley, II. Provinces of Huesca and Zaragoza. Final Technical Report. Contract No. DA-91-591-EUC-1424. http://hdl.handle.net/10261/136375.

Albareda JM, Monturiol F, Guerra A, Pérez-Mateos J, García-Vicente J, Alonso JJ. 1960. Study of the soils of the Ebro Valley, I. Provinces of Logroño and Navarra. Final Technical Report. Contract No. DA-91- 591-EUC-1085. http://hdl.handle.net/10261/134999

Artieda O, Herrero J, Drohan PJ. 2006. A refinement of the differential water loss method for gypsum determination in soils. Soil Science Society of America Journal 70: 1932-1935.

Ayers AD, Vázquez A, De la Rubia J, Blasco F, Samplón S. 1960. Saline and sodic soils of Spain. Soil Science 90: 133-138.

Beltrán F. 2006. An irrigation decree from Roman Spain: the 'Lex Rivi Hiberiensis'. The Journal of Roman Studies 96: 147-197.

Bolea-Foradada JA. 1986. Los riegos de Aragón, $2^{\text {nd }}$ edn. Zaragoza: Spain. 
Braun-Blanquet J, Bolòs O. 1957. Les groupements végétaux du Bassin Moyen de l'Ebre et leur dynamisme. Anales de la Estación Experimental de Aula Dei 5: 1-266. http://hdl.handle.net/10261/10216

Casby-Horton S, Herrero J, Rolong NA. 2015. Gypsum soils - their morphology, classification, function, and landscapes. Advances in Agronomy 130: 231-290.

De los Ríos F. 1984a. El agua en la cuenca del Ebro. Institución Fernando el Católico: Zaragoza, Spain; 141.

De los Ríos F. 1984b. Los pueblos de Colonización. In Heraldo de Aragón. Spain: Zaragoza.2701-1984.

Escavy JI, Herrero MJ, Arribas ME. 2012. Gypsum resources of Spain: temporal and spatial distribution. Ore Geology Reviews 49: 72-84.

Faci G. 1959. Ensayo de revestimientos de canales sobre terrenos yesosos. Revista de Obras Públicas 107: 497-504.

Fatás G, Beltrán M. 1997. Salduie, ciudad ibérica. Ayuntamiento de Zaragoza: Spain.

FAO. 1986. Soil survey investigations for irrigation. FAO Soils Bulletin No. 42. FAO, Rome.

FAO. 1990. Management of gypsiferous soils. FAO Soils Bulletin No. 62. FAO, Rome.

Gómez-Ayau E. 1961. El Estado y las grandes zonas regables. Instituto de Estudios Agrosociales, Ministerio de Agricultura: Madrid; 144.

Guerra A, Monturiol F. 1970. Mapa de suelos de las provincias de Zaragoza, Huesca y Logroño. CSIC: Madrid (68 pages + three maps). http://hdl.handle.net/10261/122744.

Guerra A, Guitián F, Paneque G, García-Rodríguez A, Sánchez-Fernández JA, Monturiol F, Mudarra JL. 1968. Mapa de Suelos de España. Escala 1/1 000 000, Península y Baleares. CSIC: Madrid (xiii + 117 pages + map). http://hdl.handle.net/ 10261/61769.s

Hernando V, Sánchez Conde MP, García Contreras J. 1963. Influencia de los niveles de yeso y de humedad en la fertilidad de un suelo yesoso. Anales de Edafología y Agrobiología 22: 323-337. http://hdl.handle.net/10261/136384.

Herrero J, Mandado J. 2016. Clarifications on statements in Badía et al. (2013), Geoderma 193194, 13-21. Geoderma 275: 82-83.

Herrero J, Poch RM. 1998. Preface. Special issue soils with gypsum. Geoderma 87: vii-viii. 
Herrero J, Porta J. 1991. Aridisols of Spain. In Characterization, classification and utilization of cold aridisols and vertisols, Kimble JM (ed). USDA, Soil Conservation Service, NSSC: Lincoln, NE; 61-66.253 pages

Herrero J, Artieda O, Hudnall WH. 2009. Gypsum, a tricky material. Soil Science Society of America Journal 73: 1757-1763.

Herrero J, Artieda O, Weindorf DC. 2016. Soil gypsum determination. Methods of soil analysis, Vol. 1. Soil Science Society of America: Madison, WI.

Huguet del Villar E. 1925. Avance geobotánico sobre la pretendida estepa central de España. Ibérica 580: 344-350.

Huguet del Villar E. 1929. Geobotánica. Labor: Barcelona, Spain. 339 pages

Johnston IM. 1941. Gypsophily among Mexican plants. Journal of the Arnold Arboretum 22: 145-170.

Kubiëna WL. 1952. Claves sistemáticas de suelos. Consejo Superior de Investigaciones Científicas: Madrid. English edition: Kubiëna WL. 1953. The soils of Europe. CSIC, Madrid, and Thomas Murby \& Co., London. Digital copies of the Kubiëna's book are available in three languages.

Spanish: http://simurg.bibliotecas.csic.es/viewer/image/CSIC000035789/1/LOG 0000/;

German: http://simurg.bibliotecas.csic.es/viewer/image/CSIC000074055/1/LOG 0000/;

English: http://simurg.bibliotecas.csic.es/viewer/image/CSIC000074095/1/LOG 0000/

Laya D, Van Ranst E, Herrero J. 1998. A modified parametric index to estimate yield potentials for irrigated alfalfa on soils with gypsum in Quinto (Spain). Geoderma 87: 111-122.

Lebron I, Herrero J, Robinson DA. 2009. Determination of gypsum content in dryland soils exploiting the gypsum-bassanite phase change. Soil Science Society of America Journal 73: 403-411.

Le Houérou HN. 1960. Contribution à l'etude des sols du sud tunisien. Annales agronomiques 11: $241-308$.

Llamas MR. 1958. Los yesos de la cuenca del Ebro y su repercusión en los canales de regadío. Boletín de la Real Sociedad Española de Historia Natural 55: 447-475.

Macau F, Riba O. 1962. Situación, características y extensión de los terrenos yesíferos en España. I Coloquio Internacional sobre las Obras Públicas en los Terrenos Yesíferos. 
Servicio Geológico de Obras Públicas. Ministerio de Obras Públicas: Madrid; 29 pages + two maps.

220 Mariño MG (ed). 1986. Sistema integrado del Ebro: estudio interdisciplinar. Gráf. Hermes: Madrid; 728. ISBN: 84-398-7293-3.

Moret-Fernández D, Herrero J. 2015. Effect of gypsum content on soil water retention. Journal of Hydrology 528: 122-126.

Navas A. 1991. The pattern of gypsum transport in the Ebro river network. Catena 18: 45-49.

Parsons RF. 1976. Gypsophily in plants-a review. American Midland Naturalist 96: 1-20.

Pearson MJ, Monteith SE, Ferguson RR, Hallmark CT, Hudnall WH, Monger HC, Reinsch TG, West LT. 2015. A method to determine particle size distribution in soils with gypsum. Geoderma 237-238: 318-324.

Poch RM, Artieda O, Herrero J, Lebedeva-Verba M. 2010. Gypsic features. In Interpretation of micromorphological features of soils and regoliths, Stoops G, Marcelino V, Mees F (eds). Their relevance for pedogenic studies and classifications: Elsevier; 195-216.

Ruiz M. 1977. Métodos rápidos para laboratorios de mecánica de suelos. Determinación de humedad mediante vacío y volumetría del anión sulfato, aplicadas a suelos con yeso en la construcción de la autopista del Ebro. Revista de Obras Públicas 124: 857-863. and sampling soils. Natural Resources Conservation Service, National Soil Survey Center: Lincoln, NE. Version 3.0

Soil Survey Staff. 1999. Soil taxonomy. A basic system of soil classification for making and interpreting soil surveys, $2^{\text {nd }}$ edn. USDA, National Resources Conservation Service. US Govt. Printing Office: Washington, DC.

Stoops G, Ilaiwi M. 1981. Gypsum in arid soils: morphology and genesis. In Proceedings of the Third International Soil Classification Workshop, Beinroth FH, Osman A (eds). The Arab Center for the Studies of Arid Zones and Dry Lands (ACSAD): Damascus; 175-178.

Tamés C, Peral T. 1965. Ensayos rápidos semicuantitativos para la caracterización de suelos con fines agrícolas, $3^{\text {rd }}$ edn. Instituto Nacional de Investigaciones Agronómicas. Ministerio de Agricultura: Madrid; 73. 
Van Alphen JG, De los Ríos F. 1971. Gypsiferous soils - notes on their characteristics and management. The Netherlands: Wageningen; 44. Bulletin 12. International Institute for Land Reclamation and Improvement.

\section{Figure captions}

Figure 1. The arid landscape on the Miocene gypsum rock outcropping in Alfajarín, Spain, hosts valuable biodiversity. Plowing is restricted to the flat bottoms of the valleys, filled with gypsum and fine materials detached from the slopes. The density of the gypsophilous vegetation is related to the aspect of the slope.

Figure 2. Gypsic soil horizon developed near Zaragoza, Spain. This flour-like gypseous material is common at the toeslopes of the flat-bottomed valleys. The composition of the pictured soil is $99 \%$ gypsum.

Figure 3. Sink hole in a gypseous soil in Penelles, Spain, cultivated with chamomile (Matricaria chamomilla L.). These flour-like materials, with $>60 \%$ gypsum, easily dissolve under irrigation.

\section{Supplementary material}

The transcript of a Report (in Spanish) by F. de los Ríos appeared in the published article. 


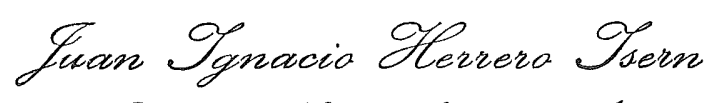

Qlnidad Nacional, 8, 9. - $\mathscr{A}$

Zleosaca

- a 17 de octubre del 1983

Sr. Do Francisco de los Rlos Romero

Camino de las Torres, 35

ZARAGOZA.-

Muy señor mío:

En su obra "Gypsiferous soils" viene citado su trabajo "Terre nos yesososoen el valle del Ebro" $\left(I \cdot \mathrm{N}_{0} \mathrm{C}_{0}\right)$.

Tras varias gestiones infructuosas para localizarlo, me decido a dirigirme a vd. por si pudiera factitame algún ejemplar de dicho trabajo.

Agradeciendo de antenano su atención, queda a su cntera dispo sición su s. S.. 
Francisca de los eRías ePamera Laragaza
Fernando el Catálica, 12

Geléfano 257899

Sr. D. Juan Ignacio Herrero Isern

Huesca.

$$
\text { Distinguido amigo: }
$$

El trabajo "Terrenos yesosos en el Valle del Ebro" no fué publicado; fué simplemente un informe que redacté en la Delegación del Ebro del Instituto Nacional de Colonización. Puede ser que tengan algún ejemplar en sus actuales oficinas, hoy IRYDA (Vazquez de Mella 8. Zaragoza) o en la Central del mismo Organismo en Madrid en el Paseo de la Castellana, creo que en el 116.

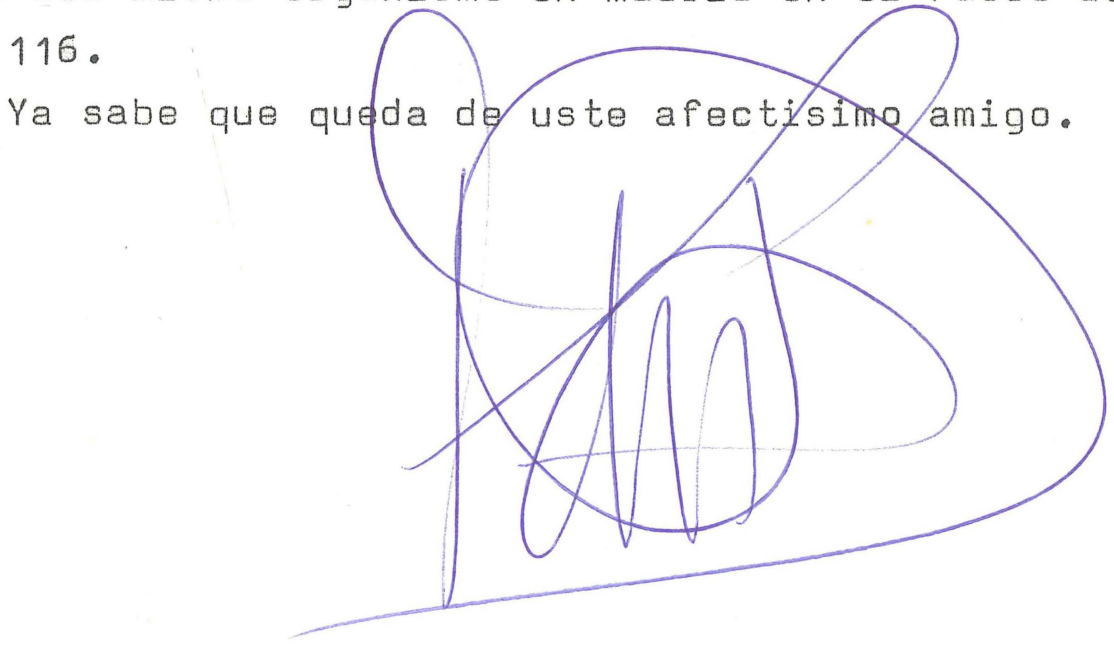

